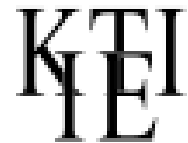

MÜHELYTANULMÁNYOK
INSTITUTE OF ECONOMICS

HUNGARIAN ACADEMY OF SCIENCES

DISCUSSION PAPERS

MT-DP. 2004/13

EXPLAINING CORRUPTION:

A COMMON AGENCY APPROACH

NORBERT MAIER

Institute of Economics

Hungarian Academy of Sciences

Budapest 


\section{EXPLAINING CORRUPTION:}

\section{A COMMON AGENCY APPROACH}

NORBERT MAIER

Budapest

August 2004 
KTK/IE Discussion Papers 2004/13

Institute of Economics Hungarian Academy of Sciences

KTK/IE Discussion Papers are circulated to promote discussion and provoque comments. Any references to discussion papers should clearly state that the paper is preliminary. Materials published in this series may subject to further publication.

The paper selected for the $4^{\text {th }}$ Budapest Summer Workshop for young economists, organised by the KTI/IE on 29-30 June 2004.

The Budapest Summer Workshops intend to bring together young economists with foreign $\mathrm{PhD}$ education, frequently still working or studying abroad.

\title{
Explaining Corruption: A Common Agency Approach
}

\author{
Author: Norbert MAIER, London Business Shcool Economics Department. \\ Regent's Park, London, NW1 4SA, UK. E-mail: nmaier@london.edu
}

I am indebted to József Molnár and Gábor Virág for helpful comments and to Marco Ottaviani for overall guidance. All remaining errors are mine.

\section{HU ISSN 1785-377X}

ISBN 9639588121

Published by the Institute of Economics Hungarian Academy of Sciences, Budapest, 2004.

With financial support from the Hungarian Economic Foundation 
The Publications of the Institute of Economics

BUDAPEST WORKING PAPERS ON THE LABOUR MARKET

\begin{tabular}{|c|c|c|}
\hline BWP 2003/1 & Ágnes Hárs & $\begin{array}{l}\text { Channeled East-West labour migration in the frame of bilateral } \\
\text { agreements }\end{array}$ \\
\hline BWP 2003/2 & Galasi Péter & $\begin{array}{l}\text { Munkanélküliségi indikátorok és az állásnélküliek munkaerő-piaci } \\
\text { kötődése }\end{array}$ \\
\hline BWP 2003/3 & Károly Fazekas & $\begin{array}{l}\text { Effects of foreign direct investment on the performance of local } \\
\text { labour markets - The case of Hungary }\end{array}$ \\
\hline BWP 2003/4 & Péter Galasi & Estimating wage equations for Hungarian higher-education graduates \\
\hline BWP 2003/5 & Péter Galasi & Job-training of Hungarian higher-education graduates \\
\hline BWP 2003/6 & $\begin{array}{l}\text { Gábor Kertesi and } \\
\text { János Köllö }\end{array}$ & $\begin{array}{l}\text { The Employment Effects of Nearly Doubling the Minimum Wage - } \\
\text { The Case of Hungary }\end{array}$ \\
\hline BWP 2003/7 & $\begin{array}{l}\text { Nemes-Nagy J. - } \\
\text { Németh N. }\end{array}$ & $\begin{array}{l}\text { A "hely" és a "fej". A regionális tagoltság tényezői az ezredfor- } \\
\text { duló Magyarországán }\end{array}$ \\
\hline BWP 2003/8 & Júlia Varga & $\begin{array}{l}\text { The Role of Labour Market Expectations and Admission Probabilities } \\
\text { in Students' Application Decisions on Higher Education: the case of } \\
\text { Hungary }\end{array}$ \\
\hline BWP 2004/1 & Gábor Kertesi & The Employment of the Roma - Evidence from Hungary \\
\hline BWP 2004/2 & Kézdi Gábor & $\begin{array}{l}\text { Az aktív foglalkoztatáspolitikai programok hatásvizsgálatának mód- } \\
\text { szertani kérdései }\end{array}$ \\
\hline BWP 2004/3 & Galasi Péter & $\begin{array}{l}\text { Valóban leértékelődtek a felsőfokú diplomák? A munkahelyi követel- } \\
\text { mények változása és a felsőfokú végzettségű munkavállalók } \\
\text { reallokációja Magyarországon 1994-2002 }\end{array}$ \\
\hline BWP 2004/4 & Galasi Péter & $\begin{array}{l}\text { Túlképzés, alulképzés és bérhozam a magyar munkaerőpiacon } \\
\text { 1994-2002 }\end{array}$ \\
\hline
\end{tabular}

RESEARCH IN LABOUR ECONOMICS

(Volumes based on conferences organised by KTK/IE and the Labour Science Committee HAS)

Munkaerőpiac és regionalitás az átmenet időszakában. Budapest, 1998.

Ed.: K. Fazekas

A munkaügyi kapcsolatok rendszere és a munkavállalók helyzete. Budapest, 2000.

Ed.: J.

Koltay

Oktatás és munkaerőpiaci érvényesülés. Budapest, 2001.

Ed.: A.

Semjén

A felzárkózás esélyei - Munkapiaci látlelet a felzárkózás küszöbén. Budapest, 2003. Ed.: Gy. Kővári

\section{LABOUR MARKET YEARBOOKS}

Munkaerőpiaci tükör - 2000. Budapest, 2000.

Munkaeröpiaci tükör - 2001. Budapest, 2001.

Munkaerőpiaci tükör - 2002. Budapest, 2002.

Munkaerőpiaci tükör - 2003. Budapest, 2003.

The Hungarian Labour Market - Review and Analysis, 2002. Bp., 2002

The Hungarian Labour Market - Review and Analysis, 2003. Bp., 2003

Budapest Working Papers on the Labour Market is jointly published by the Labour Research Department, Institute of Economics Hungarian Academy of Sciences and the Department of Human Resources, Budapest University of Economics and Public Administration. Copies are available from: Ms. Irén Szabó, Department of Human Resources, Budapest University of Economics, and Public Administration. H-1093 Budapest, Fővám tér 8. Phone/fax: 36-1 217-1936 E-mail: iszabo@workecon.bke.hu; Ms. Zsuzsa Sándor, Library of the Institute of Economics, H-1502 Budapest P.O. Box 262, Fax: 36-1 309-2649; E-mail: biblio@econ.core.hu. Papers can be downloaded from the homepage of the Institute of Economics: www.econ.core.hu 


\begin{tabular}{|c|c|c|}
\hline MT-DP. 2003/1 & $\begin{array}{l}\text { NACSA Beáta - SERES } \\
\text { Antal }\end{array}$ & $\begin{array}{l}\text { Az éves munkaidő-elszámolás, mint a munkaidő flexi- } \\
\text { bilizációjának egyik eszköze }\end{array}$ \\
\hline MT-DP. 2003/2 & $\begin{array}{l}\text { Giovanni PERI - Dieter } \\
\text { URBAN }\end{array}$ & $\begin{array}{l}\text { The Veblen-Gerschenkorn Effect of FDI in Mezzo- } \\
\text { giorno and East Germany }\end{array}$ \\
\hline MT-DP. 2003/3 & $\begin{array}{l}\text { Robin MASON - Ákos } \\
\text { VALENTINYI }\end{array}$ & $\begin{array}{l}\text { Independence, Heterogeneity and Uniqueness in } \\
\text { Interaction Games }\end{array}$ \\
\hline MT-DP. 2003/4 & $\begin{array}{l}\text { M.B.DEVEREUX-C. ENGEL } \\
\text {-P.E. STORGAARD }\end{array}$ & $\begin{array}{l}\text { Endogenous Exchange Rate Pass-through when } \\
\text { Nominal Prices are Set in Advance }\end{array}$ \\
\hline MT-DP. 2003/5 & Richard FRIBERG & Common Currency, Common Market? \\
\hline MT-DP. 2003/6 & $\begin{array}{l}\text { David C. PARSLEY- } \\
\text { Shang-Jin WEI }\end{array}$ & $\begin{array}{l}\text { The Micro-foundations of Big Mac Real Exchange } \\
\text { Rates }\end{array}$ \\
\hline MT-DP. 2003/7 & $\begin{array}{l}\text { J.IMBS - H. MUMTAZ - } \\
\text { M.O. RAVN - H. REY }\end{array}$ & $\begin{array}{l}\text { PPP Strikes Back: Aggregation and the Real Ex- } \\
\text { change Rate }\end{array}$ \\
\hline MT-DP. 2003/8 & $\begin{array}{l}\text { A. BURSTEIN -M. EICH- } \\
\text { ENBAUM - S. REBELO }\end{array}$ & Why is inflation so low after large devaluations? \\
\hline MT-DP. 2003/9 & MAJOROS Krisztina & $\begin{array}{l}\text { A múlt század jeles magyar közgazdásza: Varga Ist- } \\
\text { ván (1897-1962) }\end{array}$ \\
\hline MT-DP. 2003/10 & KOVÁCS Ilona & A fogyasztói árindex torzító tényezői \\
\hline MT-DP. 2003/11 & $\begin{array}{l}\text { Mária CSANÁDI-Hairong } \\
\text { LAI }\end{array}$ & $\begin{array}{l}\text { Transformation of the Chinese party-state at prefecture } \\
\text { and county level }\end{array}$ \\
\hline MT-DP. 2003/12 & Ilona KOVÁCS & Biasing Factors of the Consumer Price Index \\
\hline MT-DP. 2003/13 & Attila HAVAS & $\begin{array}{l}\text { Socio-Economic and Developmental Needs: Focus } \\
\text { of Foresight Programmes }\end{array}$ \\
\hline MT-DP. 2004/1 & Attila HAVAS & $\begin{array}{l}\text { Assessing the Impact of Framework Programmes in a } \\
\text { System in Transition }\end{array}$ \\
\hline MT-DP. 2004/2 & $\begin{array}{l}\text { Max GILLMAN-Michal } \\
\text { KEJAK }\end{array}$ & $\begin{array}{l}\text { Inflation and Balanced-Path Growth with Alternative } \\
\text { Payment Mechanisms }\end{array}$ \\
\hline MT-DP. 2004/3 & $\begin{array}{l}\text { L. AMBRUS-LAKATOS- } \\
\text { B. VILÁGI-J. VINCZE }\end{array}$ & $\begin{array}{l}\text { Deviations from interest rate parity in small open } \\
\text { economies: a quantitative-theoretical investigation }\end{array}$ \\
\hline MT-DP. 2004/4 & $\begin{array}{l}\text { HALPERN László és } \\
\text { szerzőtársai }\end{array}$ & A minimálbér költségvetési hatásai \\
\hline MT-DP. 2004/5 & FALUVÉGI Albert & $\begin{array}{l}\text { A társadalmi-gazdasági jellemzők területi alakulása } \\
\text { és várható hatásai az átmenet időszakában }\end{array}$ \\
\hline MT-DP. 2004/6 & Mária CSANÁDI & $\begin{array}{l}\text { Budget constraints in party-states nested in power rela- } \\
\text { tions: the key to different paths of transformation }\end{array}$ \\
\hline MT-DP. 2004/7 & Mária CSANÁDI & $\begin{array}{l}\text { A comparative model of party-states: the structural } \\
\text { reasons behind similarities and differences in self- } \\
\text { reproduction, reforms and transformation }\end{array}$ \\
\hline MT-DP. 2004/8 & KARSAI Judit & $\begin{array}{l}\text { Helyettesítheti-e az állam a magántőke-befektetőket? } \\
\text { Az állam szerepe a magántőke-piacon }\end{array}$ \\
\hline MT-DP. 2004/9 & Judit KARSAI & $\begin{array}{l}\text { Can the state replace private capital investors? Public } \\
\text { financing of venture capital in Hungary }\end{array}$ \\
\hline MT-DP. 2004/10 & Mária CSANÁDI & $\begin{array}{l}\text { Are specifics of the Chinese transformation suf- } \\
\text { ficient to avoid system demise? }\end{array}$ \\
\hline MT-DP. 2004/11 & $\begin{array}{l}\text { István CZAJLIK - János } \\
\text { VINCZE }\end{array}$ & $\begin{array}{l}\text { Corporate law and corporate governance. The } \\
\text { Hungarian experience }\end{array}$ \\
\hline MT-DP. 2004/12 & L. HALPERN et al & $\begin{array}{l}\text { Firms' Price Markups and Returns to Scale in } \\
\text { Imperfect Markets: Bulgaria and Hungary }\end{array}$ \\
\hline
\end{tabular}

Copies of both series are available from Ms. Zsuzsa Sándor, Library of Institute of Economics H-1502 Budapest P.O.Box 262 Fax: (36-1) 309-2649 E-mail: biblio@econ.core.hu. Papers can be downloaded from the homepage of the Institute of Economics: www.econ.core.hu 
MT-DP. 2004/13

\author{
EXPLAINING CORRUPTION: \\ A Common Agency Approach
}

BY NORBERT MAIER

\begin{abstract}
In many cases, politicians and government officials are forbidden by law to accept monetary donations from interest groups or other outside parties as these monetary transfers are thought to cause social inefficiencies. The empirical literature supports this view as it finds a negative link between corruption (secret payments to government officials) and growth. However, banning monetary transfers to government officials might be discouraged as it is equivalent to restricting transactions in the market for political decision-making and inefficiencies can arise exactly because of these constraints. In this paper, we address the following question: Under which conditions should the government forbid its officials to accept monetary donations, even though enforcing such bans is costly and secret transfers still may occur? In particular, we analyze a common agency game, in which a government official acts as the common agent of the government and some third party, and identify some conditions under which banning economic interactions between the official and the third party is welfare enhancing. We also explain why secret monetary transfers to government officials can lead to economic inefficiencies.

Keywords: Corruption, Bribing, Common Agency, Exclusive Dealing, Hidden Contracting

JEL Classification: C72, D62, D73, K42, P16
\end{abstract}




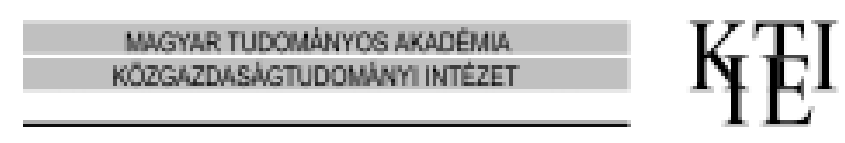

MÜHELYTANULMÁNYOK
DISCUSSION PAPERS

MT-DP. 2004/13

MAIER NORBERT

A KORRUPCIÓ ELEMZÉSE

EGY TÖBBMEGBÍzÓS MEGBÍZÓ-ÜGYNÖK KERETBEN

\section{Összefoglalás}

A törvény nagyon sok esetben megtiltja, hogy a politikusok pénzadományokat fogadjanak el érdekcsoportoktól vagy a privátszféra egyéb szereplőitöl, mivel ezek a juttatások társadalmi hatékonyságvesztéshez vezethetnek. Ennek a vélekedésnek az empirikus irodalom sem mond ellent, mivel a vizsgálatok a korrupció és a gazdasági növekedés között negatív kapcsolatot mutatnak ki. Másrészröl viszont, a privát szféra szereplöitöl a közigazgatásban dolgozóknak juttatott pénzadományokat nem kellene megtiltani, hiszen ez a politikai döntések piacán lévö tranzakciók korlátozásával egyenértékü, és éppen ezeknek a piaci tranzakcióknak a korlátozása vezethet hatékonyságvesztéshez. Dolgozatomban a következö kérdésre keresem a választ: Milyen feltételek mellett kellene a kormányzatnak megtiltania, hogy az alkalmazottai pénzadományokat fogadjanak el a privát szféra képviselöitöl, feltételezve, hogy egy ilyen tiltás betartatása költséges, hiszen a pénzmozgásokat titokban lehet tartani. A problémát egy többmegbizós megbizó-ügynök játék keretében elemzem, amelyben a közigazgatási alkalmazott a kormányzat és a privát szféra képviselöjének közös ügynöke, és megvizsgálom, hogy milyen feltételek mellett növeli a közigazgatási alkalmazott és a privát szféra közötti pénzmozgások betiltása a társadalmi összhasznot. Ezt követöen rámutatok, hogy a közigazgatási alkalmazottaknak titokban fizetett adományok hatékonyságvesztéshez vezetnek. 


\section{Introduction}

Many of the government's tasks are delegated to bureaucrats. Bureaucrats among others - decide about transfers to supporters, award contracts to private firms, collect taxes, issue licences, create government projects or regulations. These types of decisions have a strong impact on the wellbeing of private firms or interest groups and as a result, it is in the latters' interest to try to influence bureaucrats' decisions. The most effective ways for this are collecting and sharing information with them ${ }^{1}$ or offering monetary donations.

These monetary donations can be of the form of campaign financing contributions, lobbying money or direct monetary transfers in exchange for favorable decisions, and are often restricted by the law as they might distort bureaucrats' ex-ante optimal decisions. For example, campaign financing is constrained in many countries, lobbying is allowed in the United States, but not specially welcome in Europe, etc. In turn, direct monetary payments to bureaucrats are considered almost always illegal, but they still occur secretly. These instances of hidden monetary flows to politicians are called corruption. More precisely, corruption is a situation, in which a bureaucrat takes an action in exchange for some hidden monetary payment.

Economists can approach the issue of donations to politicians in a completely different way. Banning monetary transfers to politicians is equivalent to restricting transactions in the market of political decision-making and inefficiencies can arise exactly because of these constraints. This is an argument supporting the view that donations to politicians should not be limited.

As it can be seen, the issue of monetary donations to politicians and bureaucrats is a controversial one and as such, it is a fertile area of research. Aspects of the problem have been addressed both on the theoretical and the empirical side. In particular, empirical literature on corruption (see Mauro (1995)) has found a negative link between corruption and growth, which means that corruption impedes efficient economic performance and it is socially inefficient.

The theoretical literature has not yet been able to provide a unified treatment of donations to politicians and bureaucrats and therefore, different papers analyze different situations in which monetary transfers may occur.

One of the most developed area of research looks at campaign financing donations and lobbying (see Besley-Coate (2001) and Coate and Morris (1995) and Pratt (2002)). The aim of monetary transfers in these cases is to improve the electoral chances of political candidates with similar preferences. As lobbying and campaign financing donations are allowed for in many countries, this strand of research is least relevant for our purpose.

More close to our interest is the literature on monetary flows other than compaign financing donations and lobbying. In some situations the decision taken by a bureaucrat affects the wellbeing of more than one player. In some cases, the bureaucrat has to decide about awarding a government contract to

\footnotetext{
${ }^{1}$ see Austen-Smith (1995)
} 
private sector agents and it is in the applicants' interest to influence bureaucrats' decisionmaking (see Rose-Ackerman (1975)). In other cases, a benevolent government wants to correct some existing market failure and corruption arises as a consequence of agency problems within the government (see Banerjee (1997) and Acemoglu-Verdier (2000)).

In other instances, a particular decision taken by the bureaucrat affects the wellbeing of just one player (e.g. a firm). One common example is tax collection, when the bureaucrat can be bribed to misreport the firm's profit and make it pay lower taxes (see Tirole (1992)). In other cases, the government has the task of issuing licences and the bureaucrat may decide to set a price for licences (bribe) and restrict the number of licenses issued (see Shleifer and Vishny (1993)).

Most of the theoretical work on money flows to politicians looks at these transfers as being inefficient and develop a theory of second best ${ }^{2}$ to derive the equilibrium value of corruption ${ }^{3}$. However, no theoretical foundation for why these transfers are necessarily inefficient is provided.

Some of the papers realize the importance of the agency relationship between the government and its bureaucrats. In this framework, the bargaining power is given to the bureaucrat in his private (possibly hidden) relationship with the private sector agents who are willing to buy some favours from him. This is a correct assumption for situations, in which the government wants to award a contract or wants to correct market failure. However, in some other situations, like tax collection or a private firm contacting an bureaucrat with some specific request (e.g. a license or overlooking anticompetitive behavior), i.e. situations in which this realtionship is not initiated by the bureaucrat, the bargaining power allocated to the private firm might be a better approach. This is even more so, because in most cases the outside parties contacting a bureaucrat can observe his existing relationship with the government.

In our paper we build a model in which bargaining power in the relationship between private firm and bureaucrat is given to the firm. In particular, we examine the effect of monetary transfers to bureaucrat in a common agency framework, in which the bureaucrat acts as a common agent of the government and a firm (possibly a private firm). In this influencing game, principals move sequentially, i.e. when the private firm wants to set up a deal with the bureaucrat, the latter's contract with the government is already fixed. By analyzing this common agency game, we derive conditions under which it is socially efficient for the government to ban monetary transfers paid to bureaucrats. We also model the case, when legal bans on donations to politicians are not fully effective or enforceable, i.e. monetary transfers still can occur secretly, and show that these money flows lead to economic inefficiencies.

The sequence of action in our influencing game is as follows. The government delegates some of its tasks to an bureaucrat, the actions of whom it cannot costlessly observe ${ }^{4}$. After being appointed by the government, the bureaucrat

\footnotetext{
${ }^{2}$ or a general equilibrium theory in earlier papers.

${ }^{3}$ These papers often provide some mostly institutional remedies to reduce the equilibrium amount of corruption.

${ }^{4}$ For the ease of exposition, we will use the pronoun "he" for the official, "she" for the third
} 
may be contacted by a firm. The firm has an objective function that differs from the one of the government. As a result, it might be in her interest to use some monetary resources to influence the bureaucrat's decision.

We also assume that when the government appoints the bureaucrat, it has to take into account that third parties may want to contact him later on. Depending on what the government knows about these third parties, it may or may not forbid the bureaucrats to interact with them. It also has to take into account that even if it bans this type of interactions, they might occur secretly. The government includes its possible exclusivity requirement in its contract with the bureaucrat. However, these exclusivity requirements are not always effective, as secret relationships with the firm still may occur. To be able to assess the consequences of this enforcement failure, we analyze both cases when costless enforcement of exclusivity is and is not possible.

First, we investigate the case when the government is able to enforce exclusivity (effective exclusivity) and derive conditions under which it is optimal for the government to impose it. In particular, when the objectives of the government and the firm are similar, the government will be indifferent between imposing exclusivity or not. The firm will not choose to contact the bureaucrat in this case as she can free-ride on the government. Even though the government moves first, it cannot freeride on the firm as the latter one cannot be forced to enter the game. When the difference between the objectives of the firm and the government is of medium degree, it might be in the interest of the government to require exclusivity from the bureaucrat. The reason for this is that in this case, it will be in the firm's interest to contact the bureaucrat, however, the surplus created (and extracted by the government) by this interaction will be smaller than what the government could get by imposing exclusivity. Finally, when the objectives of the firm and the government are very different, it might be in the government's interest to allow for non-exclusivity and as a first mover, to extract the large surplus the firm can obtain from contacting the bureaucrat.

The more general finding here is that exclusivity might increase the players total surplus, when the contract between one principal and the agent influences the terms of the contract between the other principal and the agent. In particular, if these contractual externalities are strongly negative, exclusion might be welfare enhancing ${ }^{5}$. We show that with all the players being risk neutral, the government can implement the socially efficient outcome and in some cases, it is efficient for the government to impose a ban on contracting with third parties.

Second, we investigate the case when the government is not able to enforce exclusivity (non-enforceable exclusivity). In this scenario, the bureaucrat may choose to accept hidden donations from the firm. The government can forecast secret money flows and it may choose to launch a costly investigation and punish the other two parties if they are found to be guilty. By analyzing this scenario, we find that efficiency can be assured in many cases, both when the government's

party intending to influence his choices (this is a tradition in principal-agent relationships) and "it" for the government.

${ }^{5}$ This idea of welfare enhancing exclusivity is borrowed from Bernheim and Whinston (1998). 
and the firm's objectives are very similar (with exclusivity and non-exclusivity leading to the same outcome) or are very different (non-exclusivity chosen independently of whether exclusivity can or cannot be imposed).

We find that efficiency fails in the case when the difference between the government's and the bureaucrat's objectives is of medium degree. In one case, when this difference is lower within this medium range, the firm will choose to occasionally influence the bureaucrat's decision, even if she might be caught and punished. However, the gains from such an influencing activity are not large enough (the firm does not even choose to always influence the bureaucrat) to compensate the government for the losses that it incurs when opting for non-exclusivity. Because of this, the government will try to ban this type of contracting in the hope that a ban (with the consequence of possible punishment) will lower the firm's incentives to contact the agent. Exclusivity will be chosen in the case of no secret contracting as well, and the source of inefficiency is that the agent will choose different actions in the secret contracting and the no secret contracting case.

The other case when inefficiency can arise is when the conflict of interest between the government and the firm is higher within the medium range mentioned above. The incentives of the firm to influence the bureaucrat are stronger than previously, and it is in the interest of the government to choose non-exclusivity as it can extract all the surplus of the firm and it also knows that it would not be able to costlessly enforce exclusivity. In the no secret contracting case, the government will still opt for exclusivity as the possibility of secret contracting will not erode its power. So, in this case, not only the bureaucrat will take different actions compared to the case of no secret contracting, but the government's decision about exclusivity will differ too.

As a result, we find circumstances under which the influencing game with non-enforceable exclusivity can lead to socially suboptimal outcomes. In this cases secret contracting between the firm and the bureaucrat may occur and it is sometimes discovered. Observe that these are exactly the features of corruption and our story supports the idea that donations to bureaucrats should be banned in some cases and that non-enforceable ban can lead to economic inefficiencies, i.e. corruption destroys social efficiency.

There are two key features of our model. First, the interaction between the government and firm via the bureaucrat gives rise to contractual externalities among them in the sense that the contract between the government and the bureaucrat affects the terms of the optimal contracts between the firm and the bureaucrat and vice versa. According to Bernheim and Whinston (1998), exclusivity can be welfare enhancing if these contractual externalities are negative. This result helps us to argue that under some conditions it is socially optimal for the government to forbid its bureaucrat to accept monetary transfers from outside parties.

Second, we assume that secret donations to the bureaucrat can occur even if that has been previously forbidden by the government. Under some conditions, this distorts the contract choice of the government as the possibility for secret contracting between the firm and the bureaucrat puts an additional constraint 
on the government's optimization problem and as a result, the socially efficient solution cannot be achieved. This is exactly what happens in cases of corruption and our theory supports the view that corruption indeed leads economic inefficiency.

It is exactly these two features that are necessary to explain corruption. Without these two features, we are in the world described by Bernheim and Whinston (1986) who claim that with no contractual externalities (feature 1) and observable contracts (feature 2) the total joint surplus of the players (principals and agent) can be maximized, i.e. social efficiency can be achieved.

We organize the rest of the paper as follows. We introduce the elements of our model in Section 2. We derive and characterize the equilibrium of the game when exclusivity can be costlessly enforced and no secret contracting occurs in Section 3. We perform the same analysis for the case when secret contracting can occur in Section 4 and we conclude in Section 5.

\section{The model}

We analyze a model in which a firm wants to influence the actions taken by a bureaucrat. The details of the economic environment are as follows.

The government represents the aggregate welfare of the society in the sense that its payoffs coincides with the values of the aggregate social welfare ${ }^{6}$ and it delegates some of its tasks to an bureaucrat. Also assume that there is uncertainty in this environment, in the sense that two states of the world can occur. Denote state 1 as the "good" state and state 2 as the "bad" state as the payoff of the government (and that of the social welfare) is higher in state 1. The bureaucrat's task is to choose the probability of the good state to occur. Assume that he has to make a binary choice, i.e. pick a probability $p$ from the set $\{\underline{p}, \bar{p}\}(\underline{p}, \bar{p} \in(0,1)$ and $\underline{p}<\bar{p})$ of the good state (state 1$)$ to occur.

The terms of the contract offered to the bureaucrat are designed by the government. The bureaucrat acts as the agent of the government. The principalagent relationship between the two of them has three specific features.

First, because of high monitoring costs, the government is not able to perfectly observe the actions of the bureaucrat, it can only observe the state of the world realized, which is in turn influenced by the agent's action.

Second, the government offers a flat wage payment to the bureaucrat. This assumption can be justified by the fact that elements of the bureaucrats' work (involving a series of activities and decisions) are hard to measuregenerally.

The third specific feature of this principal-agent relationship is that it involves the possibility of reputation building by the bureaucrat. In particular, the occurrence of state 1 (the good state) increases his opportunities of receiving better jobs or promotions in the future ${ }^{7}$.

\footnotetext{
${ }^{6}$ including that of the third party as well.

${ }^{7}$ see Tirole (1994) for a comprehensive discussion of the role of soft incentives (flat wage) and reputation within government agencies.
} 
The benefits of the bureaucrat are thus twofold: he receives a flat wage from the government and he can derive a reputation rent when the good state of the world occurs. On the cost side, one can assume that there is no difference in the cost of choosing any particular value of the probability of the good state to occur. This assumption can be justified by the fact that even though it is costly for the bureaucrat to gather information to prepare a given decision, the cost of decision-making itself does not depend on the outcome of the decision. Therefore, there is no loss of generality in normalizing the costs of the bureaucrat to zero.

The expected utility of the bureaucrat in this simple setup can be written as

$$
u=w^{g}+p A
$$

where $w^{g}$ denotes the flat wage received from the government and $A$ is a positive real number quantifying the reputation rent of the bureaucrat in the good state ${ }^{8}$. The expected payoff of the government can be written as

$$
v^{g}=p q_{1}^{g}+(1-p) q_{2}^{g}-w^{g}
$$

where $q_{1}^{g}$ and $q_{2}^{g}$ are positive real numbers, $q_{1}^{g}>q_{2}^{g}$, denoting the government's payoffs in the good state and the bad state, respectively. Players are risk neutral in this setup because we would like to focus on issues other than risk-sharing.

Extend this setup by including a firm who wants to influence the decisions taken by the bureaucrat by monetary means. Interacting with the firm may distort the decision of the bureaucrat from what the government would like to obtain. As a result, the government may choose to put a ban on this type of interactions. One of our main assumption is that this type of interactions might occur even if the government forbids them, they just happen secretly.

The firm's payoffs also depend on the state of the world and it might be in her interest to try to influence the bureaucrat's actions using monetary transfers. Because of this, the interaction between the firm and the bureaucrat can also be modelled as a principal-agent relationship, in which the former is the principal and the latter is the agent ${ }^{9}$.

However, there are two differences between the two relationships the bureaucrat becomes involved in. First, the firm is able to observe the bureaucrat's action. This is not a crucial assumption from the technical point of view, but we think that when a firm wants to influence the decision of a bureaucrat on a particular issue, she is well informed about that issue and in many cases joint consultations are often part of their interaction. Second, since the agreement between the firm and the bureaucrat might be secret (and illegal), its terms cannot be enforced by law. We solve this problem by allowing for some exogenous

\footnotetext{
${ }^{8}$ In the bad state he does not derive any reputation rent.

${ }^{9}$ We shortly discussed the choice of allocating the bargaining power to the third party in the introduction. In particular, we justify this choice by the fact that in many cases it is generally the third party who contacts the government official in a particular issue and not the bureaucrat is holding an auction to receive some compensation in exchange for favours.
} 
reputation mechanism ${ }^{10}$ to control for the two parties' behavior.

Assume therefore that the payoffs of the firm depend on the state of the world and the only cost it incurs is the choice contingent monetary transfer paid to the bureaucrat. The firm's expected payoff can be written as

$$
v^{f}=p q_{1}^{f}+(1-p) q_{2}^{f}-w^{f}(p)
$$

where $q_{1}^{f}$ and $q_{2}^{f}$ are real numbers denoting the firm's payoffs in state 1 (the good state) and state 2 (the bad state) and $w^{f}(p)$ denotes the choice contingent wage paid to the bureaucrat. By taking into account a possible interaction with a firm, the expected payoff of the bureaucrat has to be rewritten as

$$
u=w^{g}+w^{f}(p)+p A
$$

The bureaucrat has a reservation utility value denoted by $u_{0}$ for the case of not accepting the contract offered by the government.

It can be seen that in the extended model the bureaucrat acts as a common agent of the government and the firm. As a result, the interaction of the three players can be modelled as a common agency game with the principals moving sequentially. The timing of this influencing game is the following.

In the first stage, the government offers an exclusive or a non-exclusive contract to a future bureaucrat who decides whether to accept that contract or not.

In the second stage, the firm observes the contract between the government and the bureaucrat ${ }^{11}$ and decides whether to offer a contract to the bureaucrat or not.

In the third stage, the bureaucrat decides whether to accept or not the contract offered by the firm. Afterwards, he takes an action, i.e. he chooses the probability of the good state to occur. After the choice of the bureaucrat, the state of the nature realizes.

In the fourth stage, the government - provided that it chose an exclusive contract in the first stage -, decides whether to conduct a costly investigation or not to discover whether secret contracting between the firm and the bureaucrat occurred. If an investigation finds the other two parties guilty, they will be punished. Finally, payoffs are realized.

Observe that the payoff structure of the players in (1)-(4) does not contain any elements of the firm's (possibly) random choice whether to offer a contract to the bureaucrat, of the government's decision to launch an investigation or of the agent having an expected utility under exclusivity with separate terms for both cases of being offered a contract by the firm or not. We will formalize these elements later on in the paper.

\footnotetext{
${ }^{10}$ For example, if the third party does not make the money transfer in compensation for a decision favourable for her, she will risk that the official will never act in her favour in the future. Alternatively, if the official does not deliver the right decision, he risks of not being contacted later on in his work. However, this mechanism is observed to work well in some cases, and less well in others (see Shleifer and Vishny (1993) for a short discussion).

${ }^{11}$ The main terms (e.g. salary) of these contracts are generally public or are common knowledge.
} 
Before starting the equilibrium analysis, some additional clarifying remarks have to be done. First, the assumption that the government cannot observe the actions of the bureaucrat is essential because if the action chosen by the bureaucrat would be perfectly observable by the government, it could immediately find out whether subsequent contracting between the firm and the bureaucrat occurred. In that case the firm will always be punished when contracting with the bureaucrat and as a result, this type of contracts might be completely eliminated and no secret influence activity by the firm (corruption) will take place.

Second, imposing risk neutrality for the bureaucrat is without loss of generality as we would like to identify forces other than risk sharing in explaining influencing practices. In addition, risk neutrality implies transferable utilities which allows us to assume that when caught of secretly contracting, only the firm will be punished ${ }^{12}$.

The assumption of the firm's payoffs to be common knowledge is not restrictive as it only abstracts from information rent issues that are well documented in the information economics literature.

Now we can turn to analyze the common agency game between the government, the bureaucrat and the firm. In the next section we analyze the game in which the government can effectively ban contracting between the bureaucrat and the firm if it chooses so. The analysis of this simpler game provides a first insight into the mechanisms at work and also helps to derive the socially optimal outcome of the influencing game. Then we turn to the analysis of the influencing game with non-enforceable exclusivity in Section 4 . Section 5 concludes.

\section{The benchmark case - No secret contracting}

In this section we analyze the case when the government is able to enforce a ban on contracting between the bureaucrat and the firm at zero cost. This case explains the motivation of the government to require exclusivity from its bureaucrat and it also provides important guidelines to evaluate the efficiency of the various contractual arrangements ${ }^{13}$. We can turn afterwards in Section 4 to analyze the case when the government is not able to enforce such bans.

The timing in this simpler game is as follows.

In the first stage, the government offers an exclusive or a non-exclusive contract to an bureaucrat.

In the second stage, the firm observes this contract and if it is non-exclusive she decides whether to offer a contract to the bureaucrat or not.

In the third stage, the bureaucrat decides whether to accept or not the contract offered by the firm. Then, he takes an action, i.e. he chooses the

\footnotetext{
${ }^{12}$ If the agent would be punished as well, the payment made by the third party should be increased by this amount to compensate the agent for expected loss, which is identical to the third party paying a punishment that is higher by the amount of the official's punishment.

${ }^{13}$ Our analysis resembles some of the results obtained in Bernheim and Whinston's (1998) seminal work on exclusive dealing.
} 
probability of the good state to occur. Afterwards, the state of the nature realizes.

In the fourth stage, payoffs are realized.

This simpler game is still a common agency game, with the principals moving sequentially. The strategy sets of the players can be identified as follows. The government has to make an exclusivity decision and to choose a wage (which is not state-dependent) afterwards. Its strategy set therefore contains the set $\{E, N E\}$ and the set $W^{g}$ of functions $w^{g}:\{E, N E\} \rightarrow R_{+}$. The strategy of the firm involves choosing an action-contingent payment to the bureaucrat when the government opts for non-exclusivity, so her strategy space is the set $w^{f}$ of functions $w^{f}: R_{+} \times\{E, N E\} \times P \rightarrow R$, where $P=\{p, \bar{p}\}$ and $w^{f}\left(R_{+}, E, P\right)=$ 0 . Finally, the bureaucrat's strategy space is the set of functions $p: R_{+} \times$ $\{E, N E\} \times w^{f} \rightarrow P$.

The equilibrium of this influencing game $\Gamma_{1}$ is a probability $p$ chosen by the bureaucrat and a set of contracts chosen by the government and the firm such that the chosen probability maximizes the utility of the bureaucrat, taken the contracts he is offered as given, whereas the contracts chosen by the government and the firm maximizes their objective function subject to the probability chosen by the agent and the contract chosen by the other principal. The following definition formalizes the equilibrium concept.

Definition 1 A pure strategy equilibrium of the influencing game $\Gamma_{1}$ is a vector $\left\{\widehat{e}, \widehat{w}^{g}, \widehat{w}^{f}, \widehat{p}\right\}$, such that

1, for every $\widehat{w}^{f} \in w^{f}$ and $\widehat{p} \in P$,

$$
\begin{aligned}
\left(\widehat{e}, \widehat{w}^{g}\right) \in \arg \max _{e, w^{g}(e)}\left\{\widehat{p}\left(e, w^{g}(e), \widehat{w}^{f}\left(w^{g}(e), e, \widehat{p}\right)\right) q_{1}^{g}+\right. \\
\left.\quad+\left(1-\widehat{p}\left(e, w^{g}(e), \widehat{w}^{f}\left(w^{g}(e), e, \widehat{p}\right)\right)\right) q_{2}^{g}-w^{g}(e)\right\}
\end{aligned}
$$

2, for every $\left(N E, \widehat{w}^{g}\right) \in\{E, N E\} \times W^{g}$ and $\widehat{p} \in P$,

$$
\widehat{w}^{f} \in \arg \max _{w^{f}}\left\{\widehat{p}\left(N E, \widehat{w}^{g}, w^{f}\right) q_{1}^{f}+\left(1-\widehat{p}\left(N E, \widehat{w}^{g}, w^{f}\right)\right) q_{2}^{f}-w^{f}\right\}
$$

3, for every $\left(\widehat{e}, \widehat{w}^{g}\right) \in\{E, N E\} \times W^{g}$ and $\widehat{w}^{f} \in w^{f}$,

$$
\widehat{p} \in \arg \max _{p}\left\{\widehat{w}^{g}+\widehat{w}^{f}\left(\widehat{e}, \widehat{w}^{g}, p\right)+p A\right\}
$$

Since the principals move sequentially in this game, the equilibrium of the game can be found by backward induction. Remember, that the optimization of the government includes an exclusivity choice. Since this is the first choice made in the game, we split the game $\Gamma_{1}$ into two subgames: $\Gamma_{1}^{e}$, the subgame when government requires exclusivity from the bureaucrat, and $\Gamma_{1}^{n e}$, in which contracting with the firm is allowed. We analyze the optimal contracts in the two subgames and derive conditions that drive the government's exclusivity decision.

The following proposition summarizes the outcome of the subgame when exclusivity is imposed effectively, i.e. no secret contracting occurs. 
Proposition 1 The choice of $\bar{p}$ is always implemented in the subgame with exclusive contracting and the equilibrium outcomes are as follows:

1 , the bureaucrat's utility is kept at its reservation level $u_{0}$.

2, the firm's expected payoff is

$$
v^{f}=\bar{p} q_{1}^{f}+(1-\bar{p}) q_{2}^{f}
$$

3, the government's expected payoff is

$$
v^{g}=\bar{p} q_{1}^{g}+(1-\bar{p}) q_{2}^{g}-u_{0}+\bar{p} A
$$

Proof. See Appendix.

The results in Proposition 1 can be easily understood. There is no conflict of interest between the government and the bureaucrat as both of them derives higher expected utility net of payments from the bureaucrat choosing probability $\bar{p}$. Since both of them are risk neutral, they can maximize their joint surplus ${ }^{14}$ even if the action taken by the bureaucrat is not directly observed by the government and the latter is able to extract all the surplus from the former. The firm is a passive player in this game, so she does not make and receive any monetary payment. Her payoff is given by equation (8). One should note here that the payoff in equation (8) will act as a reservation payoff for the firm in the subgame with non-exclusive contracting since she can always get this payoff by not offering a contract to the bureaucrat ${ }^{15}$.

The case of non-exclusive contract offered by the government is more complex. As the government moves first by setting the value of the wage paid to the bureaucrat at $w^{g}$, the firm makes her decision taking this value as given. As $w^{g}$ will not change in response to the bureaucrat's action, she is basically facing a simple agency problem when designing the optimal incentive scheme for the bureaucrat. The firm's optimization problem can be written as:

$$
\begin{aligned}
& \max _{w^{f}}\left\{p q_{1}^{f}+(1-p) q_{2}^{f}-w^{f}(p)\right\} \\
& \text { s.t. } p \in \arg \max _{p}\left\{w^{g}+w^{f}(p)+p A\right\}
\end{aligned}
$$

It can be seen that the wage paid by the government only shifts the bureaucrat's reservation utility value, and as such, it cannot influence the choice of $p$.

Lemma 1 In the subgame with non-exclusivity, the action chosen by the bureaucrat is only influenced by the firm. In particular, $\bar{p}$ is chosen in the equilibrium if and only if the following condition holds:

$$
q_{1}^{f}-q_{2}^{f} \geq-A
$$

\footnotetext{
${ }^{14}$ First-best can be achieved by selling the firm to the agent.

${ }^{15}$ The government will not able to unilaterally manipulate this incentive by setting the wage $w^{g}$ at a low level, because if the third party will choose to stay passive, the official will have an incentive to choose $\bar{p}$.
} 
The transfer paid by the firm to the bureaucrat is equal to

$$
w^{f}(p)=u_{0}-p A-w^{g}
$$

Proof. See Appendix.

Recall that the distinction between the good state and the bad state was arbitrary. State 1 was chosen to be the good state because we assumed that the payoff of the government (which is supposed to represent aggregate social welfare) was higher in state 1 , i.e. $q_{1}^{g}>q_{2}^{g}$. As a result, the condition described in Lemma 1 can be interpreted as follows: If the conflict of interest between the government and the firm is not too large (i.e. $q_{1}^{f}-q_{2}^{f}$ is also positive or does not have a large negative value), then the government's optimal choice, $\bar{p}$, will be implemented, or, in other words, it doesn't pay off for the firm to induce the bureaucrat to choose an action that he favours less, since her payoff in state 2 is not sufficiently high relative to the payoff in state 1 to compensate him for the increased agency costs.

So, the equilibrium value of $p$ will depend only on the firm's payoffs in the two states of the world and since these two values are known to the government, it can calculate the equilibrium value of $p$ in advance. The only tool of the government in this subgame is setting the value of $w^{g}$. One can see that the higher $w^{g}$, the lower the wage paid by the firm has to be in order to keep the bureaucrat at his reservation utility. As a result, the government can use $w^{g}$ to extract surplus from the firm. In particular, the lower $w^{g}$, the more the firm has to pay to the bureaucrat to keep him at his reservation utility, and the lower the firm's surplus. However, there is a lower bound on the firm's surplus. In particular, the firm must be assured an expected payoff not lower than the one in equation (8) in order to induce her to participate in the game. The equilibrium outcome of the subgame with non-exclusivity is as follows.

Proposition 2 The equilibrium outcome and the payoffs in the subgame with non-exclusivity are as follows:

1, The bureaucrat's utility is kept at its reservation level $u_{0}$.

2, The firm's expected payoff is also kept at its reservation level given by equation (8).

3, The bureaucrat's equilibrium action and the government's payoff depend on the firm's payoffs in the two states of the world. In particular:

$i$, if condition (11) holds, the bureaucrat chooses

$$
p=\bar{p}
$$

and the equilibrium payoff of the government is equal to

$$
v^{g}=\bar{p} q_{1}^{g}+(1-\bar{p}) q_{2}^{g}-u_{0}+\bar{p} A
$$

ii, of condition (11) does not hold, the bureaucrat chooses

$$
p=\underline{p}
$$


and the equilibrium payoff of the government is equal to

$$
v^{g}=\underline{p} q_{1}^{g}+(1-\underline{p}) q_{2}^{g}-u_{0}+\underline{p} A-(\bar{p}-\underline{p})\left(q_{1}^{f}-q_{2}^{f}\right)
$$

Proof. See Appendix.

The next step of our analysis is to identify the set of conditions that drive the government's exclusivity decision. Compare the government's payoffs under both regimes, i.e. to compare the expressions in equation (9), (14) and (16). Observe that the expressions in equations (9) and (14) are the same. The reason is that the equilibrium action of the bureaucrat is the same in the two cases and the firm is kept at the same payoff in both cases. In the first case, she is a passive player and receives her reservation expected payoff. In the second case, all her surplus is transferred to the government via the wage $w^{g}$, and as a result she will act like an intermediary agent of no use and no harm. This means that under condition (11), the government is indifferent between offering an exclusive or a non-exclusive contract to the bureaucrat.

When condition (11) does not hold, exclusivity and non-exclusivity are not any more equivalent for the government. The following theorem summarizes the conditions for exclusivity to be optimal.

Theorem 1 The government's incentives to offer exclusive contract to the bureaucrat can be summarized as follows:

1, If condition (11) holds, the government is indifferent between exclusivity and non-exclusivity.

2, If condition (11) does not hold, the government will opt for exclusivity for the bureaucrat if and only if

$$
q_{1}^{f}-q_{2}^{f}>-A-\left(q_{1}^{g}-q_{2}^{g}\right)
$$

Proof. See Appendix.

Condition (17) provides an important insight. When the magnitude of the conflict between the objectives of the government and the firm passes a certain limit, i.e. condition (11) fails to hold, the firm's expected payoff is higher when she can influence the bureaucrat to choose his less preferred action $(\bar{p})$. However, when the difference between the objectives of the two is not vary large, i.e. condition (17) holds as well, this gain in the expected payoff of the firm will be less than the loss in the expected payoff of the government when it allows for non-exclusivity and the bureaucrat chooses his less preferred action. In this case it is optimal for the government to choose exclusivity.

However, when the conflict of interest between the government and the firm is very high, i.e. condition (17) is violated too, the surplus created by the firm from influencing the bureaucrat becomes large enough to even compensate the government for switching to non-exclusivity.

Observe too, that under exclusive contracting, the government is able to extract all the surplus of the bureaucrat (above the reservation level), whereas 
under non-exclusive contracting it is the firm who is able to extract all the surplus of the bureaucrat (above the reservation level) and the government is in turn able to extract all the surplus of the firm (above the reservation level). As a result, all the realized surplus goes to the government and the choice of exclusivity by the government assures that the maximal joint surplus of the players will be realized. It is interesting to see that under condition (17), imposing exclusivity enhances the joint surplus of the players.

This idea, i.e. that exclusive dealing can enhance the total surplus of the players is shown more generally in Bernheim and Whinston (1998). The main idea behind this result is that contractual externalities might lead to inefficiencies. In particular, the value of the difference $q_{1}^{f}-q_{2}^{f}$ influences the contract that the firm offers to the bureaucrat. However, the terms of this contract affects the contract that the government offers to the bureaucrat. In this sense there might be negative contractual externalities between the principals, in the sense that under some conditions the government can make a higher payoff with banning contracting for the firm rather then allowing it.

This argument supports the idea that in some cases exclusivity will lead to a higher joint surplus of the players and in turn a higher payoff for the government as it is able to extract all the surplus of the other two players. Since the government is assumed to represent aggregate welfare, this means that requiring exclusivity maximizes social welfare under condition (17). As a result, a ban on subsequent contracting for bureaucrats can increase aggregate social welfare and as such it can be rationalized. The following corollary formalizes this idea.

Corollary 1 When there is no cost of enforcing exclusivity, the government can always implement the socially efficient outcome. In addition, if condition (17) holds, this requires imposing exclusivity in the contracts offered to bureaucrats.

We can now turn to the case when exclusivity cannot be costlessly enforced and see how the statements of the theorem and its corollary change.

\section{The case of secret contracting}

Let us now investigate the case when secret contracting between the firm and the bureaucrat may occur. In this case, the government cannot perfectly observe the bureaucrat's action, it can only draw inferences about possible secret contracting by observing the realized state of the world. Since any investigation ${ }^{16}$ is costly for the government, assume that it will launch on investigation only if state 2 (the state that gives it a lower payoff) occurred. If an investigation finds

\footnotetext{
${ }^{16}$ From this point on, we use the worlds "secret contracting" for contracting between the third party and the official that occured in spite of the ban imposed by the government, and "investigation" for an investigation launched by the government to discover whether such secret contracting occured or not.
} 
evidence of secret contracting, the firm will be punished ${ }^{17}$. The magnitude of punishment, $T$, is taken to be exogenously fixed by law.

Observe that the players in this game may make random choices, i.e. once exclusivity is imposed by the government, the firm may choose not to always offer a contract to the bureaucrat, or the government might choose not to always investigate. In particular, the firm offers a contract to the bureaucrat with some probability $s$ and the government investigates with some probability $t$. This opens up the possibility of mixed strategy equilibria of the subgame in which the government imposes exclusivity but cannot costlessly enforce it, so secret contracting may occur.

The expected payoffs of the players when exclusivity is non-enforceable are as follows. The expected payoff of the bureaucrat can be written as

$$
u=s\left[w^{g}+w^{f}(\widetilde{p})+\widetilde{p} A\right]+(1-s)\left[w^{g}+p^{\prime} A\right]
$$

where $\widetilde{p}$ is the probability chosen by the bureaucrat under secret contracting (which occurs with probability $s$ ) and $p^{\prime}$ is the probability chosen when no contract by the firm is offered. The objective function of the firm when she decides to offer a contract to the bureaucrat has the following form

$$
v^{f}=p q_{1}^{f}+(1-p)\left(q_{2}^{f}-t T\right)-w^{f}(p)
$$

otherwise she receives her reservation value determined in equation (8). Observe that the payoff in state 2 (the bad state) is lowered by the expected amount of punishment in case of government investigation. The overall objective function of the firm that takes into account the choice of secretly offering a contract to the bureaucrat with probability $s$, can be written as

$$
v^{f}=s\left[\widetilde{p} q_{1}^{f}+(1-\widetilde{p})\left(q_{2}^{f}-t T\right)-w^{f}(\widetilde{p})\right]+(1-s)\left[p^{\prime} q_{1}^{f}+\left(1-p^{\prime}\right) q_{2}^{f}\right]
$$

Finally, the objective function of the government can be written as

$$
\begin{aligned}
v^{g}= & {\left[s \widetilde{p}+(1-s) p^{\prime}\right] q_{1}^{g}+t\left[s(1-\widetilde{p})+(1-s)\left(1-p^{\prime}\right)\right]\left(q_{2}^{g}-c+s T\right)+} \\
& +(1-t)\left[s(1-\widetilde{p})+(1-s)\left(1-p^{\prime}\right)\right] q_{2}^{g}-w^{g}
\end{aligned}
$$

The terms of this expression can be understood as follows. State 1 of the world occurs with probability $\widetilde{p}$ when the firm offers a contract to the bureaucrat (and this occurs in turn with probability $s$ ) and with probability $p^{\prime}$ when the firm does not offer a contract to the bureaucrat (with probability $(1-s)$ ). The probability for state 2 to occur can be calculated in a similar way. In addition, the government will launch an investigation in state 2 with probability $t$ which has a cost of $c$ and has a return of $T$ (the amount of the punishment $)^{18}$ when

\footnotetext{
${ }^{17}$ We do not consider any other punisment mechanisms (e.g. firing the official or decreasing the amount of reputational rent in the future) as all these punishment have a monetary equivalent.

${ }^{18} \mathrm{~A}$ direct money transfer from the third party to the government in case of punishment is a strong assumption. If the money that the third party has to pay if caught of bribing is
} 
evidence of secret contracting is found (with probability $s$ ). The government's objective function can be written in a more concise form as

$$
v^{g}=\left[s \widetilde{p}+(1-s) p^{\prime}\right] q_{1}^{g}+\left[s(1-\widetilde{p})+(1-s)\left(1-p^{\prime}\right)\right]\left[q_{2}^{g}+t(-c+s T)\right]-w^{g}
$$

Review shortly the timing of the game presented in Section 2.

In the first stage, the government offers an exclusive or a non-exclusive contract to an bureaucrat.

In the second stage, after observing the contract between the government and the bureaucrat, the firm chooses to offer a contract to the bureaucrat with some probability.

In the third stage, the bureaucrat takes an action and the state of the world realizes.

In the fourth stage, the government chooses a probability to investigate provided that it imposed exclusivity in the first stage. If evidence of secret contracting is found, the parties will be punished. Finally, payoffs are realized.

The strategy space of the players can be identified as follows.

The government has to make an exclusivity decision, to choose a wage (which is not state-dependent) and a probability of investigation in state 2 . Its strategy set $W^{g}$ therefore contains the set $\{E, N E\}$, and the set of functions $w^{g}:\{E, N E\} \rightarrow R^{+}$and $t:\{E, N E\} \rightarrow[0,1]$, with $t(N E)=0$. The firm has to choose a probability $s$ to offer a contract to the bureaucrat (this is a secret contract when exclusivity is required by the government), and a statedependent payment schedule $w^{f}$. Her strategy space $w^{f}$ contains the set of functions $s: R_{+} \times\{E, N E\} \times P \rightarrow[0,1]$ and $w^{f}: R_{+} \times\{E, N E\} \times P \rightarrow R$, where $P=\{\underline{p}, \bar{p}\}$. Finally, the bureaucrat's strategy space $P$ contains three elements $^{19}$, the set $\widetilde{P}$ of functions, $\widetilde{p}: R_{+} \times\{E, N E\} \times w^{f} \rightarrow P$ specifying the action taken under contracting with the firm and the set $P^{\prime}$ of functions $p^{\prime}: R_{+} \times\{E, N E\} \rightarrow P$ specifying the action taken when not contracting with the firm.

The equilibrium of this contracting game $\Gamma_{2}$ is a pair of probabilities $\left(\widetilde{p}, p^{\prime}\right)$ chosen by the bureaucrat, and a set of contracts and a probability chosen by both the government and the firm such that the chosen probability maximizes the utility of the bureaucrat, taken the contracts he is offered as given, whereas the contracts and the probabilities chosen by the government and the firm maximizes their objective function subject to the probability chosen by the bureaucrat and the contract and the probability chosen by the other principal. The following definition formalizes the equilibrium concept.

Definition 2 An equilibrium of the contracting game $\Gamma_{2}$ is a vector $\left\{\widehat{e}, \widehat{w}^{g}, \widehat{t}, \widehat{s}, \widehat{w}^{f}, \widehat{\widetilde{p}}, \widehat{p}^{\prime}\right\}$, such that

burned, our equilibrium does not work. However, this is an other extreme case. In the real world, when a government is successful in discovering corruption, it can "score good points" from the public, which means that the monetary equivalent of its payoff in state 2 is strictly higher than the actual payoff less the cost of investigation, i.e. $q_{2}^{g}-c$. Under this assumption a slightly different equilibrium than ours will emerge and the qualitative results remain the same.

${ }^{19}$ Do not confuse the strategy space $P$ of the official with his choice set $P=\{\underline{p}, \bar{p}\}$. 
1, for every $\left(\widehat{s}, \widehat{w}^{f}\right) \in w^{f}$ and $\left(\widehat{\widetilde{p}}, \widehat{p}^{\prime}\right) \in P$,

$$
\begin{aligned}
& \left(\widehat{e}, \widehat{w}^{g}, \widehat{t}\right) \in \arg \max _{e, w^{g}(e), t(e)}\left\{\left[\widehat{s} \widehat{\widetilde{p}}\left(e, w^{g}(e), \widehat{w}^{f}\right)+(1-\widehat{s}) \widehat{p}^{\prime}\left(e, w^{g}(e)\right)\right] q_{1}^{g}+\right. \\
& \left.+\left[\widehat{s}\left(1-\widehat{\widetilde{p}}\left(e, w^{g}(e), \widehat{w}^{f}\right)\right)+(1-\widehat{s})\left(1-\widehat{p}^{\prime}\left(e, w^{g}(e)\right)\right)\right]\left[q_{2}^{g}+t(-c+\widehat{s} T)\right]-w^{g}((2) 3\}\right)
\end{aligned}
$$

2, for every $\left(\widehat{e}, \widehat{w}^{g}, \widehat{t}\right) \in W^{g}$ and $\left(\widehat{\widetilde{p}}, \widehat{p}^{\prime}\right) \in P$,

$$
\begin{gathered}
\left(\widehat{s}, \widehat{w}^{f}\right) \in \quad \arg \max _{s, w^{f}}\left\{s \widehat{\widetilde{p}}\left(\widehat{e}, \widehat{w}^{g}, w^{f}\right) q_{1}^{f}+\left(1-\widehat{\widetilde{p}}\left(\widehat{e}, \widehat{w}^{g}, w^{f}\right)\right)\left(q_{2}^{f}-\widehat{t} T\right)-w^{f}\right]+ \\
\left.+(1-s)\left[\widehat{p}^{\prime}(\widehat{e}) q_{1}^{f}+\left(1-\widehat{p}^{\prime}(\widehat{e})\right) q_{2}^{f}\right]\right\}
\end{gathered}
$$

3, for every $\left(\widehat{w}^{g}, \widehat{t}\right) \in W^{g}$ and $\left(\widehat{s}, \widehat{w}^{f}\right) \in w^{f}$,

$$
\begin{gathered}
\widehat{\widetilde{p}} \in \arg \max _{\widetilde{p}}\left\{\widehat{w}^{g}+\widehat{w}^{f}\left(\widehat{e}, \widehat{w}^{g}, \widetilde{p}\right)+\widetilde{p} A\right\} \\
\widehat{p}^{\prime} \in \arg \max _{p^{\prime}}\left\{\widehat{w}^{g}+p^{\prime} A\right\}
\end{gathered}
$$

Similarly to the previous section, the principals move sequentially and the equilibrium of the game can be found by backward induction. It also makes sense, as before, to split the game into two subgames $\left(\Gamma_{2}^{e}\right.$ and $\left.\Gamma_{2}^{n e}\right)$, conditional on whether the government chooses exclusivity or non-exclusivity in the first stage. The case of non-exclusivity, including the final payoffs of the players, is exactly the same as in the previous section and therefore, we only derive here the equilibrium of subgame $\Gamma_{2}^{e}$. The analysis goes through the following steps:

Step 1. Analyze the bureaucrat's actions $\widetilde{p}$ and $p^{\prime}$ and derive the wage paid by the firm.

Step 2. Analyze the firm's decision whether to contract with the bureaucrat or not, taking the government's decision about the probability to investigate as given.

Step 3. Examine the government's decision whether to investigate or not, taking the firm's decision whether to contract secretly or not as given.

Step 4. Solve for their optimal choice of these two probabilities.

The bureaucrat has to make a double choice, i.e. to choose a probability $\widetilde{p}$ when being offered a contract and a probability $p^{\prime}$ when not contracting with the firm. In the latter case the bureaucrat receives only a flat rate wage from the government and his optimization problem can be written as

$$
\max _{p^{\prime}}\left\{w^{g}+p^{\prime} A\right\}
$$

Since the wage offered by the government is not contingent on the chosen action, the bureaucrat chooses

$$
p^{\prime}=\bar{p}
$$


When contracting with the bureaucrat, the firm offers a choice contingent wage. The bureaucrat's choice can therefore be determined by solving the firm's optimization problem

$$
\begin{aligned}
& \max _{w^{f}}\left\{\widetilde{p} q_{1}^{f}+(1-\widetilde{p})\left(q_{2}^{f}-t T\right)-w^{f}(\widetilde{p})\right\} \\
& \text { s.t. } \tilde{p} \in \arg \max _{\widetilde{p}}\left\{s\left[w^{g}+w^{f}(\widetilde{p})+\widetilde{p} A\right]+(1-s)\left[w^{g}+p^{\prime} A\right]\right\}
\end{aligned}
$$

The following lemma describes the bureaucrat's optimal choice and the wage that he receives from the firm.

Lemma 2 In the subgame with non-enforceable exclusive contracting, the firm offers the bureaucrat a payment schedule of the following form:

$$
w^{f}(\widetilde{p})=-(\widetilde{p}-\bar{p}) A+\frac{1}{s}\left(u_{0}-\bar{p} A-w^{g}\right)
$$

The bureaucrat chooses $\widetilde{p}=\bar{p}$ in equilibrium if and only if

$$
q_{1}^{f}-q_{2}^{f} \geq-A-t T
$$

Proof. See Appendix.

It can be seen that the possibility of punishment lowers the firm's expected payoff in state 2 , and as a result, weakens her incentives to make the bureaucrat to choose his less preferred action. By similar arguments to those in Section 3 , the bureaucrat's utility will be kept at its reservation value (at this stage the equilibrium value of $w^{g}$ is not yet calculated). Similarly to Lemma 1, the bureaucrat's choice does not depend on the wage offered by the government.

Beside designing a contract for the bureaucrat, the firm also has to choose a probability $s$ of offering such a contract. In particular, she chooses a value for $s$ that maximizes her expected payoff

$v^{f}=s\left[\widetilde{p} q_{1}^{f}+(1-\widetilde{p})\left(q_{2}^{f}-t T\right)+(\widetilde{p}-\bar{p}) A-\frac{1}{s}\left(u_{0}-\bar{p} A-w^{g}\right)\right]+(1-s)\left[\bar{p} q_{1}^{f}+(1-\bar{p}) q_{2}^{f}\right]$

By substituting $\bar{p}$ for $p^{\prime}$ and rearranging, the firm's expected payoff can be rewritten as

$$
v^{f}=s\left[(\widetilde{p}-\bar{p})\left(q_{1}^{f}-q_{2}^{f}+A+t T\right)-(1-\bar{p}) t T\right]+\left[\bar{p} q_{1}^{f}+(1-\bar{p}) q_{2}^{f}\right]-\left(u_{0}-\bar{p} A-w^{g}\right)
$$

The government's best response strategy is to choose a value of $t$ that maximizes its expected payoff function

$$
v^{g}=[s \widetilde{p}+(1-s) \bar{p}] q_{1}^{g}+[s(1-\widetilde{p})+(1-s)(1-\bar{p})]\left[q_{2}^{g}+t(-c+s T)\right]-w^{g}
$$

The choices of $t$ and $s$ cannot be observed for the other party even though they do not occur simultaneously. As a result, the interaction of the government and the firm can be analyzed as a simultaneous game. The following lemma presents the outcome of this game. 
Lemma 3 The equilibrium outcome $(t, s)$ of the contracting-investigating subgame between the government and the firm depends on the parameters of the model:

1, If condition (11) holds, i.e.

$$
q_{1}^{f}-q_{2}^{f} \geq-A
$$

the game has a pure strategy equilibrium in which $s=0$ and $t=0$.

2, If condition (11) does not hold, the subgame has a mixed strategy equilibrium, in which

$$
s=c / T
$$

and

$$
t=\frac{(\underline{p}-\bar{p})\left(q_{1}^{f}-q_{2}^{f}+A\right)}{(1-\underline{p}) T}
$$

Proof. See Appendix.

Some clarifying comments might help understanding the results in Lemma 3. Remember from Lemma 2, that the bureaucrat chooses $\widetilde{p}=\bar{p}$ in equilibrium if and only if condition (31) holds. As a result, $\widetilde{p}$ is a function of $t$, and this has to be kept in mind when maximizing the firm's objective function in (33), which will be discontinuous at $t=\left(q_{1}^{f}-q_{2}^{f}+A\right) / T$. Observe that in the scenario with fully mixed strategies, $\widetilde{p}=\underline{p}$ and inequality (31) does not hold.

The following proposition completes the analysis of subgame $\Gamma_{2}^{e}$ by determining the equilibrium wage offered by the government to the bureaucrat and writing down the payoff structure of the players.

Proposition 3 The equilibrium outcome of the game with non-enforceable exclusive contracting looks as follows:

1, The bureaucrat's expected utility is always kept at its reservation level. He is always choosing probability $\bar{p}$ of state 1 to occur when no contract is offered to him by the firm. However, when such contract is offered, he chooses $\bar{p}$ if and only if condition (11) holds. In addition, the wage paid to him by the government is equal to

$$
w^{g}=u_{0}-\bar{p} A
$$

2, The firm's expected payoff is also kept at its reservation level given by equation (8).

3, The bureaucrat's equilibrium action and the government's expected payoff depend on the firm's payoffs in the two states of the world, in particular:

$i$, when condition (11) holds, the bureaucrat chooses

$$
\widetilde{p}=\bar{p}, p^{\prime}=\bar{p}
$$

and the government's expected payoff is equal to

$$
v^{g}=\bar{p} q_{1}^{g}+(1-\bar{p}) q_{2}^{g}-u_{0}+\bar{p} A
$$


ii, when condition (11) does not hold, the bureaucrat chooses

$$
\widetilde{p}=\underline{p}, p^{\prime}=\bar{p}
$$

and the equilibrium payoff of the government is equal to

$$
v^{g}=\underline{p} q_{1}^{g}+(1-\underline{p}) q_{2}^{g}-u_{0}+\underline{p} A+(\bar{p}-\underline{p})\left[(1-c / T)\left(q_{1}^{g}-q_{2}^{g}\right)+A\right]
$$

Proof. See Appendix.

The following theorem formulates conditions, under which it is optimal for the government to require exclusivity from the bureaucrat, and as such it completes the analysis of the game in which secret contracting may occur in equilibrium.

Theorem 2 The government's incentives to offer exclusive contract to the bureaucrat can be summarized as follows:

1, If condition (11) holds, the government is indifferent between providing an exclusive or non-exclusive contract to the bureaucrat.

2, If condition (11) does not hold, the government will opt for exclusive contracting with the bureaucrat if and only if

$$
q_{1}^{f}-q_{2}^{f}>-A-(1-c / T)\left(q_{1}^{g}-q_{2}^{g}\right)
$$

Proof. See Appendix.

Comparing our results in Theorem 1 and Theorem 2, we can set up conditions under which the possibility of secret contracting destroys the efficiency results formulated in Corollary 1.

Theorem 3 The possibility of secret contracting leads to inefficient outcome in the following cases:

$i$, When

$$
-A \geq q_{1}^{f}-q_{2}^{f}>-A-(1-c / T)\left(q_{1}^{g}-q_{2}^{g}\right)
$$

the government will opt for exclusivity even if it is costly to enforce it. The bureaucrat chooses $\widetilde{p}=\underline{p}$ when offered a contract by the firm, as opposed to the efficient equilibrium outcome when he always chooses $p=\bar{p}$.

ii, If

$$
-A-(1-c / T)\left(q_{1}^{g}-q_{2}^{g}\right) \geq q_{1}^{f}-q_{2}^{f}>-A-\left(q_{1}^{g}-q_{2}^{g}\right)
$$

holds, the government chooses exclusivity when it can enforce it by no cost and chooses non-exclusivity when it is costly to enforce exclusivity. Furthermore, the bureaucrat chooses $\widetilde{p}=\underline{p}$ when offered a contract by the firm, as opposed to the efficient equilibrium outcome of $p=\bar{p}$. 
Proof. See Appendix.

The intuition behind this result is the following. When the conflict of interest between the government and the firm is small, the firm does not offer any contract to the agent, as he will choose his preferred action anyhow and it would be to costly for her to induce a change.

When the conflict of interest between the government and the firm passes a certain limit, i.e., inequality (43) holds, the firm's incentives to influence the bureaucrat's decision become high enough so that she chooses to offer a contract to the bureaucrat even if she might be caught and punished. As the firm's incentives for contracting with the bureaucrat are not very strong yet $(s<1)$, it is worth for the government to stick to exclusivity as switching to non-exclusivity will incur higher losses.

However, when the conflict of interest between the government and the firm is even stronger, i.e. it is inequality (44) that holds, the incentives of the firm to offer a contract to the bureaucrat are much stronger, and it is in the interest for the government to choose non-exclusivity as it can extract all the surplus of the firm and it also knows that it is costly to enforce exclusivity. Note, that it still would stick to exclusivity if it could enforce it at no cost.

Finally, when the conflict between the two principals is extremely high, it is in the government's interest to choose non-exclusivity even if it could enforce it at no cost, as the gains from extracting the firm's extra surplus from inducing the bureaucrat to switch from his preferred choice, are larger than the benefit of sticking to the choice that would be optimal if there was no firm.

Theorem 3 also provides conditions under which it is in the government's interest to impose exclusivity, but secret contracting can occur in these cases and that leads to social inefficiencies. Observe that this finding exactly supports the idea that in some cases bureaucrats should be forbidden accepting monetary donations from outside parties as they cause economic inefficiencies. However, secret transfers may occur in this cases causing additional losses of efficiency.

\section{Conclusions}

We analyzed the phenomenon of using monetary transfers to influence decisions taken by bureaucrats in a common agency framework, in which a bureaucrat acts as the common agent of the government and a firm. We identified conditions under which it is efficient for the government to forbid its bureaucrat to accept money donations from third parties and also for what happens when the ban imposed by the government can be circumvented by secret contracting. We found that inefficiencies arise in the latter case and we suggested that our results can be used to support the common view as well as empirical evidence that bribing and corruption lead to economic inefficiency under certain conditions.

Our analysis can be extended in many ways. It might be interesting to see how competition can enrich our results. First, it might be worth examing 
whether corruption can be reduced by introducing competition among bureaucrats. Second, it would be interesting to look at the case when there are more than one third parties and see how those results can be related to existing literature on the effect of the market structure of the bribers market on corruption. Testing some of the predictions of the model would also be a useful undertaking.

\section{Appendix}

Proof of Proposition 1:

The optimization problem of the government can be written as:

$$
\begin{aligned}
& \max _{w^{g}}\left\{p q_{1}^{g}+(1-p) q_{2}^{g}-w^{g}\right\} \\
& \text { s.t. } \max _{p}\left\{w^{g}+p A\right\}
\end{aligned}
$$

and the bureaucrat has a reservation utility of $u_{0}$.

Since $\bar{p}>\underline{p}$, if $w^{g}$ is constant, the bureaucrat will always choose $\bar{p}$. The government still can extract all the surplus of the bureaucrat (above the reservation level) by setting

$$
w^{g}=u_{0}-p A
$$

As a result, the payoffs in this game can be written as

$$
\begin{aligned}
v^{g} & =\bar{p} q_{1}^{g}+(1-\bar{p}) q_{2}^{g}-u_{0}+\bar{p} A \\
v^{f} & =\bar{p} q_{1}^{f}+(1-\bar{p}) q_{2}^{f} \\
u & =u_{0}
\end{aligned}
$$

Q.E.D.

Proof of Lemma 1:

The firm's optimization problem can be written as

$$
\begin{aligned}
& \max _{w^{f}(p)}\left\{p q_{1}^{f}+(1-p) q_{2}^{f}-w^{f}(p)\right\} \\
& \text { s.t. } \max _{p}\left\{w^{g}+w^{f}(p)+p A\right\}
\end{aligned}
$$

and again, the bureaucrat has a reservation utility of $u_{0}$. 
The optimal compensation scheme $w^{f}(p)$ has to be incentive compatible, which means that if the firm wants to implement choice $\widetilde{p}$, the following, inequality must hold:

$$
w^{g}+w^{f}(\widetilde{p})+\widetilde{p} A \geq w^{g}+w^{f}(p)+p A
$$

for each $p \in\{\underline{p}, \bar{p}\}$. For example, if the firm wants to implement $\bar{p}$, the following two conditions must hold:

$$
\bar{p} q_{1}^{f}+(1-\bar{p}) q_{2}^{f}-w^{f}(\bar{p}) \geq \underline{p} q_{1}^{f}+(1-\underline{p}) q_{2}^{f}-w^{f}(\underline{p})
$$

and

$$
w^{g}+w^{f}(\bar{p})+\bar{p} A \geq w^{g}+w^{f}(\underline{p})+\underline{p} A
$$

or, equivalently

$$
\begin{aligned}
(\bar{p}-\underline{p})\left(q_{1}^{f}-q_{2}^{f}\right) & \geq w^{f}(\bar{p})-w^{f}(\underline{p}) \\
\text { s.t. } w^{f}(\bar{p})-w^{f}(\underline{p}) & \geq-(\bar{p}-\underline{p}) A
\end{aligned}
$$

The second inequality will generally bind, so by substituting the LHS of the second equation into the RHS of the first equation, we get that the firm will want to implement $\bar{p}$ if and only if

$$
(\bar{p}-\underline{p})\left(q_{1}^{f}-q_{2}^{f}\right) \geq-(\bar{p}-\underline{p}) A
$$

which is equivalent to the inequality in Lemma 1. By taking into account the bureaucrat's reservation utility, the optimal compensation schedule offered by the firm is equal to

$$
w^{f}(p)=u_{0}-p A-w^{g}
$$

Q.E.D.

Proof of Proposition 2:

By looking at the compensation schedule at the end of the proof of Lemma 1 , it can be seen that the under non-exclusivity the firm is able to fully extract the bureaucrat's surplus, so his utility will be kept at the reservation level. As a result, the firm's objective function can be written as

$$
v^{f}=p q_{1}^{f}+(1-p) q_{2}^{f}-u_{0}+p A+w^{g}
$$

It can be seen that since the government offers a flat wage to the bureaucrat, it cannot influence the firm's decision of which $p$ to implement. The best what the government can do is do extract the surplus of the firm, above her reservation level given by equation (9). This gives us the optimal wage chosen by the government:

$$
w^{g}=u_{0}-p A+(\bar{p}-p)\left(q_{1}^{f}-q_{2}^{f}\right)
$$


in which the value of $p$ is determined by the firm. As a result, if the firm chooses to implement $\bar{p}$, i.e. the condition in Lemma 1 holds, the payoff function of the government can be written as

$$
v^{g}=\bar{p} q_{1}^{f}+(1-\bar{p}) q_{2}^{f}-u_{0}+\bar{p} A
$$

whereas in the case when the condition in Lemma 1 does not hold, and the firm chooses to implement $\underline{p}$, the payoff function of the government can be written as

$$
v^{g}=\underline{p} q_{1}^{g}+(1-\underline{p}) q_{2}^{g}-u_{0}+\underline{p} A-(\bar{p}-\underline{p})\left(q_{1}^{f}-q_{2}^{f}\right)
$$

Q.E.D.

Proof of Theorem 1:

From the proofs of Proposition 1 and Proposition 2 it can be seen that in the case when condition in Lemma 1 holds, and $\bar{p}$ is implemented under non-exclusive contracting, the payoff of the government coincides in the case of exclusivity and non-exclusivity. As a result, it will be indifferent between banning contracting of the firm with the bureaucrat or not.

When condition in Lemma 1 does not hold, this indifference result will not hold anymore. Comparing the objective functions of the government in this case, as in (8) and (15), we get that the government will opt for exclusivity if and only if

$$
\bar{p} q_{1}^{g}+(1-\bar{p}) q_{2}^{g}-u_{0}+\bar{p} A \geq \underline{p} q_{1}^{g}+(1-\underline{p}) q_{2}^{g}-u_{0}+\underline{p} A-(\bar{p}-\underline{p})\left(q_{1}^{f}-q_{2}^{f}\right)
$$

After rearranging and simplifying by $(\bar{p}-p)$, a positive number, we get that the government will opt for exclusivity if and only if

$$
q_{1}^{g}-q_{2}^{g}+q_{1}^{f}-q_{2}^{f}+A \geq 0
$$

By rearranging this inequality we receive the condition stated in inequality (16) in Theorem 1.

Q.E.D.

Proof of Lemma 2:

The firm's optimization problem can be written as

$$
\begin{aligned}
\max _{w^{f}(p)} & \left\{\widetilde{p} q_{1}^{f}+(1-\widetilde{p})\left(q_{2}^{f}-t T\right)-w^{f}(\widetilde{p})\right\} \\
\text { s.t. } & \max _{\widetilde{p}}\left\{s\left[w^{g}+w^{f}(\widetilde{p})+\widetilde{p} A\right]+(1-s)\left[w^{g}+p^{\prime} A\right]\right\}
\end{aligned}
$$

and again, the bureaucrat has a reservation utility of $u_{0}$. 
The optimal compensation scheme $w^{f}(p)$ has to be incentive compatible, which means that if the firm wants to implement choice $\widetilde{p}$, the following, inequality must hold:

$$
w^{g}+w^{f}(\widetilde{p})+\widetilde{p} A \geq w^{g}+w^{f}(p)+p A
$$

for each $p \in\{\underline{p}, \bar{p}\}$. For example, if the firm wants to implement $\bar{p}$, the following two conditions must hold:

$$
\bar{p} q_{1}^{f}+(1-\bar{p})\left(q_{2}^{f}-t T\right)-w^{f}(\bar{p}) \geq \underline{p} q_{1}^{f}+(1-\underline{p})\left(q_{2}^{f}-t T\right)-w^{f}(\underline{p})
$$

and

$s\left[w^{g}+w^{f}(\bar{p})+\bar{p} A\right]+(1-s)\left[w^{g}+p^{\prime} A\right] \geq s\left[w^{g}+w^{f}(\underline{p})+\underline{p} A\right]+(1-s)\left[w^{g}+p^{\prime} A\right]$

or, equivalently

$$
\begin{aligned}
(\bar{p}-\underline{p})\left(q_{1}^{f}-q_{2}^{f}+t T\right) & \geq w^{f}(\bar{p})-w^{f}(\underline{p}) \\
\text { s.t. } w^{f}(\bar{p})-w^{f}(\underline{p}) & \geq-(\bar{p}-\underline{p}) A
\end{aligned}
$$

The second inequality will generally bind, so by substituting the RHS of the second equation into the RHS of the firs equation, we get that the firm will want to implement $\bar{p}$ if and only if

$$
(\bar{p}-\underline{p})\left(q_{1}^{f}-q_{2}^{f}+t T\right) \geq-(\bar{p}-\underline{p}) A
$$

which is, after little manipulation, exactly equivalent to the inequality in Lemma 2. By taking into account the bureaucrat's reservation utility and that $p^{\prime}=\bar{p}$, we can solve for the optimal compensation schedule offered by the firm

$$
w^{f}(\widetilde{p})=-(\widetilde{p}-\bar{p}) A+\frac{1}{s}\left(u_{0}-\bar{p} A-w^{g}\right)
$$

Q.E.D.

Proof of Lemma 3:

In order to derive the equilibrium of the choice of $s$ and $t$, we need to maximize the firm's and the government's objective functions with respect to these two variables. The firm's expected payoff function is as in (33):

$v^{f}=s\left[(\widetilde{p}-\bar{p})\left(q_{1}^{f}-q_{2}^{f}+A+t T\right)-(1-\bar{p}) t T\right]+\left[\bar{p} q_{1}^{f}+(1-\bar{p}) q_{2}^{f}\right]-\left(u_{0}-\bar{p} A-w^{g}\right)$

whereas the government's expected payoff is as in (34):

$$
v^{g}=[s \widetilde{p}+(1-s) \bar{p}] q_{1}^{g}+[s(1-\widetilde{p})+(1-s)(1-\bar{p})]\left[q_{2}^{g}+t(-c+s T)\right]-w^{g}
$$

Remember from Lemma 2 that $\widetilde{p}=\bar{p}$ if and only if condition (29), i.e.

$$
q_{1}^{f}-q_{2}^{f} \geq-A-t T
$$


holds. It can be seen that there is a non-continuity in $v^{f}$ at $t^{0}=-\frac{q_{1}^{f}-q_{2}^{f}+A}{T}$.

In particular, when $t \geq t^{0}$, we have condition (31) to hold, which implies that $\widetilde{p}=\bar{p}$ and as a result, the first term inside the first square bracket of $v^{f}$ vanishes. Then the firm wants to maximize the following function

$$
v^{f}=-s(1-\bar{p}) t T+\left[\bar{p} q_{1}^{f}+(1-\bar{p}) q_{2}^{f}\right]-\left(u_{0}-\bar{p} A-w^{g}\right)
$$

If, on the contrary, $t<t^{0}$, condition (31) does not hold, we have $\widetilde{p}=\underline{p}$ and that implies that the first term inside the first square bracket of $v^{f}$ becomes a strictly positive number. Then the firm wants to maximize the following function

$$
v^{f}=s\left[(\underline{p}-\bar{p})\left(q_{1}^{f}-q_{2}^{f}+A\right)-(1-\underline{p}) t T\right]+\left[\bar{p} q_{1}^{f}+(1-\bar{p}) q_{2}^{f}\right]
$$

which can be written in a simpler form if we denote $(\underline{p}-\bar{p})\left(q_{1}^{f}-q_{2}^{f}+A\right)$ by $K$ $(K>0)$ :

$$
v^{f}=s[K-(1-\underline{p}) t T]+\left[\bar{p} q_{1}^{f}+(1-\bar{p}) q_{2}^{f}\right]
$$

To solve for the equilibrium we need to separate three cases, depending on the position of $t^{0}$ to 0 and 1 .

$1, t^{0}=-\frac{q_{1}^{f}-q_{2}^{f}+A}{T}<0$. In this case we certainly have $t \geq t^{0}$, which implies that the firm's expected payoff function is given by (A.27).

If $t>0$, we have $s=0$, which in turn makes the government choose $t=0$. Contradiction.

If $t=0$, the firm is indifferent between choosing any value of $s \in[0,1]$. The government's best response is to choose $t=0$ when $s<c / T$, to choose $t=1$ when $s>c / T$ or to choose any value in the interval $t \in[0,1]$ when $s=c / T$. The equilibrium is $t=0$ and $s \in[0, c / T]$. The firm's expected payoff is indifferent of $s$ but the government's expected payoff is a decreasing function of $s$, so all the equilibria in which $s \in(0, c / T]$ are Pareto-dominated by the one in which $s=0$, so we only keep this one.

$2,0<t^{0}=-\frac{q_{1}^{f}-q_{2}^{f}+A}{T} \leq 1$. There are two subcases here.

i, $t<-\frac{q_{1}^{f}-q_{2}^{f}+A}{T}$. In this case the firm's objective function is the one in (A.29). Remember that $K>0$.

If $K-(1-p) t T>0$, we have $s=1$, which in turn makes the government choose $t=1$. However, this equilibrium only supports for $t$ a maximum level of $t=-\frac{q_{1}^{f}-q_{2}^{f}+A}{T}-\varepsilon$, so the government is not allowed to choose a level higher than that. This equilibrium outcome is feasible only if $K-(1-\underline{p}) t T>0$, or equivalently, $K+(1-\underline{p})\left(q_{1}^{f}-q_{2}^{f}+A\right)>0$, which can be simplified to $(1-\bar{p})\left(q_{1}^{f}-q_{2}^{f}+A\right)>0$ and this is not true.

If $K-(1-p) t T<0$, we have $s=0$, which in turn makes the government choose $t=0$. This equilibrium is not feasible as $K>0$. 
If $K-(1-p) t T=0$. In this case it can be seen that the firm is indifferent between choosing any value of $s \in[0,1]$. The government's best response is to choose $t=0$ when $s<c / T$, which is not feasible as $K>0$, to choose $t=-\frac{q_{1}^{f}-q_{2}^{f}+A}{T}-\varepsilon$ (observe it is not allowed to choose $t=1$ in this case) when $s>c / T$, which is feasible only if $K=-(1-\underline{p})\left(q_{1}^{f}-q_{2}^{f}+A\right)$ (very special case, so we skip it) or to choose any value in the interval $t \in\left[0,-\frac{q_{1}^{f}-q_{2}^{f}+A}{T}\right)$ when $s=c / T$. This equilibrium is only feasible if $K=(1-\underline{p}) t T$, which implies that we have $t=K /[(1-\underline{p}) T]$ in equilibrium.

ii, $t \geq-\frac{q_{1}^{f}-q_{2}^{f}+A}{T}$. In this case we have to look at (A.27) in investigating the firm's optimal choices.

As $t>0$ in this case, the firm chooses $s=0$, which in turn makes the government choose $t=0$. Contradiction.

$3, t^{0}=-\frac{q_{1}^{f}-q_{2}^{f}+A}{T}>1$. In this case we certainly have $t<t^{0}$, which implies that the firm's expected payoff function is given by (A.29).

If $K-(1-p) t T>0$, we have $s=1$, which in turn makes the government choose $t=1$. This equilibrium outcome is feasible only if $K>(1-p) T$.

If $K-(1-p) t T<0$, we have $s=0$, which in turn makes the government choose $t=0$. This equilibrium is not feasible as $K>0$.

If $K-(1-p) t T=0$. In this case it can be seen that the firm is indifferent between choosing any value of $s \in[0,1]$. The government's best response is to choose $t=0$ when $s<c / T$, which is not feasible as $K>0$ ), to choose $t=1$ when $s>c / T$, which is feasible only if $K=(1-p) T$ (very special case, so we skip it) or to choose any value in the interval $t \in[0,1]$ when $s=c / T$. This equilibrium is only feasible if $K=(1-\underline{p}) t T$, which implies that we have $t=K /[(1-\underline{p}) T]$ in equilibrium.

Q.E.D.

\section{Proof of Proposition 3:}

The equilibrium values of $\widetilde{p}$ and $p^{\prime}$ have already been derived in equation (28) and in Lemma 2. Lemma 3 indicates that the subgame between the government and the firm has two equilibria, one in pure strategies and one in mixed strategies, depending on the parameters of the model. We are going $t$ discuss these two equilibria in turn.

$1, q_{1}^{f}-q_{2}^{f} \geq-A$. In this case, $t=0, s=0, \widetilde{p}=\bar{p}$ and $p^{\prime}=\bar{p}$.

This means that the firm does not offer a contract to the bureaucrat, and the government has to consider only the outcomes of directly contracting with the bureaucrat. In this case the wage it offers the principal has to compensate him for the choosing probability $\bar{p}$, and it will be equal to

$$
w^{g}=u_{0}-\bar{p} A
$$


By substituting all these values in the firm's objective function, it can be seen that it will be equal to

$$
v^{f}=\bar{p} q_{1}^{f}+(1-\bar{p}) q_{2}^{f}
$$

which is exactly her reservation value. In turn, the government's expected payoff function can be written as

$$
v^{g}=\bar{p} q_{1}^{g}+(1-\bar{p}) q_{2}^{g}-u_{0}+\bar{p} A
$$

$2, q_{1}^{f}-q_{2}^{f}<-A$. In this case, $t=\frac{(\underline{p}-\bar{p})\left(q_{1}^{f}-q_{2}^{f}+A\right)}{(1-\underline{p}) T}, s=c / T, \widetilde{p}=\underline{p}$ and $p^{\prime}=\bar{p}$.

The expected payoff of the bureaucrat will be equal to

$$
u=s w^{f}(\underline{p})+s \underline{p} A+(1-s) \bar{p} A+w^{g}
$$

By substituting for $w^{f}(\underline{p})$ from (30), we get that the expected utility of the bureaucrat will be kept at its reservation level again. The firm will be indifferent between offering a contract to the bureaucrat or not if and only if her expected payoff will be the same with or without offering a contact, i.e.

$$
\bar{p} q_{1}^{f}+(1-\bar{p}) q_{2}^{f}-\left(u_{0}-\bar{p} A-w^{g}\right)=\bar{p} q_{1}^{f}+(1-\bar{p}) q_{2}^{f}
$$

which implies that the wage offered by the government to the bureaucrat is the same as in equation (A.30) and the expected payoff of the firm is also kept at its reservation level given by equation (A.31). By substituting all these values into the government's expected payoff, we receive that it can will be equal to

$$
v^{g}=\underline{p} q_{1}^{g}+(1-\underline{p}) q_{2}^{g}-u_{0}+\underline{p} A+(\bar{p}-\underline{p})\left[(1-c / T)\left(q_{1}^{g}-q_{2}^{g}\right)+A\right]
$$

Q.E.D.

Proof of Theorem 2:

To derive the results of the theorem, compare the equilibrium outcomes from Proposition 2 and 3. It can be seen that the two scenarios are separated by the same condition (11) in both theorems. In particular, the expected payoff of the government is the same under non-exclusivity and non-enforceable exclusivity.

However, when condition (11) does not hold, the government chooses nonenforceable exclusivity under the following condition

$$
\begin{aligned}
& \underline{p} q_{1}^{g}+(1-\underline{p}) q_{2}^{g}-u_{0}+\underline{p} A+(\bar{p}-\underline{p})\left[(1-c / T)\left(q_{1}^{g}-q_{2}^{g}\right)+A\right]> \\
& >\underline{p} q_{1}^{g}+(1-\underline{p}) q_{2}^{g}-u_{0}+\underline{p} A-(\bar{p}-\underline{p})\left(q_{1}^{f}-q_{2}^{f}\right)
\end{aligned}
$$

or, equivalently when the following condition holds

$$
q_{1}^{f}-q_{2}^{f}>-A-(1-c / T)\left(q_{1}^{g}-q_{2}^{g}\right)
$$

Q.E.D. 
Proof of Theorem 3:

It can be seen that the indifference results formulated in point 1 , of Theorem 1 and Theorem 2, hold under the same condition (11), so no inefficiencies occur under condition (11). However, if condition (11) fails to hold, the following possibilities occur:

$\mathrm{i},-A>q_{1}^{f}-q_{2}^{f}>-A-(1-c / T)\left(q_{1}^{g}-q_{2}^{g}\right)$. In this case the efficient solution involves exclusive contracting in Theorem 1 with $p=\bar{p}$. Exclusive contracting prevails under the conditions of Theorem 2 , with the one difference that $\widetilde{p}=p$, i.e. the bureaucrat chooses an inefficient action when offered a contract by the firm.

ii, $-A-(1-c / T)\left(q_{1}^{g}-q_{2}^{g}\right) \geq q_{1}^{f}-q_{2}^{f}>-A-\left(q_{1}^{g}-q_{2}^{g}\right)$. In this case the efficient solution involves exclusive contracting in Theorem 1 with $p=\bar{p}$. However, the government chooses non-exclusive contracting under the conditions of Theorem 2 with $p=\underline{p}$.

iii, $-A-\left(q_{1}^{g}-q_{2}^{g}\right) \geq q_{1}^{f}-q_{2}^{f}$. Non-exclusive contracting with $p=\underline{p}$ will be chosen by the government in both theorems, as a result, efficient outcome is feasible even if exclusivity cannot be imposed efficiently.

Q.E.D.

\section{References}

[1] Acemoglu, D. and Verdier, T. "The Choice between Market Failures and Corruption", American Economic Review, 2000, 90(1), pp. 194-211

[2] Ades, A. and Di Tella, R. "Rents, Competition, and Corruption", American Economic Review, 1999, 89(4), pp. 982-993

[3] Aidt, T.S. "Economic Analysis of Corruption: A Survey", Economic Journal, 2003, 113, pp. F632-F652

[4] Austen-Smith, D. "Campaign Contributions and Access", American Political Science Review, (1995), 89(3), pp. 566-581

[5] Banerjee, A.V. "A Theory of Misgovernance", Quarterly Journal of Economics, 1997, 112(4), pp. 1289-1332

[6] Becker, G. and Stiegler, G. "Law Enforcement, Malfeasance and the Compensation of Enforcers", Journal of Legal Studies, 1974, 3(1), pp. 1-19

[7] Bernheim, D. and Whinston, M.D. "Menu Auctions, Resource Allocations, and Economic Influence", Quarterly Journal of Economics, 1986, 101(1), pp. $1-31$ 
[8] Bernheim, D. and Whinston, M.D. "Exclusive Dealing", Journal of Political Economy, 1998, 106(1), pp. 64-103

[9] Besley, T. and Coate, S. "Lobbying and Welfare in a Representative Democracy", Review of Economic Studies, 68(1), pp. 67-82

[10] Grossman, G. and Helpman, E. "Protection for Sale", American Economic Review, 1994, 84 (5), pp. 833-850

[11] Grossman, G. and Helpman, E. "Electoral Competition and Special Interest Politics", Review of Economic Studies, 1996, 63(2), pp.265-286

[12] Mauro, P. "Corruption and Growth", Quarterly Journal of Economics, 1995, 110(3), pp. 681-712

[13] Pratt, A. "Campaign Spending with Office-Seeking Politicians, Rational Voters, and Multiple Lobbies", Journal of Economic Theory, 2002, 103(1), pp. $162-189$

[14] Rose-Ackerman, S. "The Economics of Corruption", Journal of Public Economics, 1975, 4(1), pp. 187-203

[15] Shleifer, A. "State vs. Private Ownership", Journal of Economic Perspectives, 1998, 12(4), pp. 133-150

[16] Shleifer, A. and Vishny, R.W. "Corruption", Quarterly Journal of Economics, 1993, 108(3), pp. 599-617

[17] Shleifer, A. and Vishny, R.W. "Politicians and Firms", Quarterly Journal of Economics, 1994, 109(4), pp. 995-1025

[18] Tirole, J. "Collusion and the Theory of Organization", in (J.J. Laffont ed.) Advances in Economic Theory, Sixth World Congress vol.2, 1992, Cambridge University Press

[19] Tirole, J. "The Internal Organization of the Government", Oxford Economic Papers, 1994, 46(1), pp. 1-29 